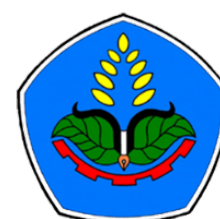

AGROPROSS

National Conference

\title{
Proceedings:
}

Peningkatan Produktivitas Pertanian Era Society 5.0 Pasca Pandemi

Tempat : Politeknik Negeri Jember

Tanggal : 22 Juli 2021

Publisher :

Agropross, National Conference Proceedings of Agriculture

ISBN : 978-623-94036-6-9

DOI : 10.25047 /agropross.2021.236

\section{Uji Toksisitas Ekstrak Daun Piairawi (Haplolobus cf. monticola Husson.) Asal Teluk Wondama dalam Mengendalikan Hama Ulat Tritip (Plutella xylostella L.) Pada Tanaman Sawi (Brassica junceae L.)}

\author{
Author(s): Sutiharni ${ }^{\left({ }^{*}\right)}$, Selpia Murarani Torey ${ }^{(2)}$, Linda Enawati Lindongi ${ }^{(1)}$, \\ Yacob Bodang ${ }^{(1)}$
}

(1) Prodi Agroteknologi, Fakultas Pertanian, Universitas Papua

(2) Alumni Agroteknologi, Fakultas Pertanian, Universitas Papua

*Corresponding author: naningmulyadi@gmail.com

\begin{abstract}
Mustard is much favored by the public as a food (vegetable) both for fresh consumption and processed, contains vitamins and nutrients that are very important for health. One of the causes of the decline in mustard production is due to the attack of the tritip caterpillar (Plutella xylostella L.) which interferes with the mustard plant cultivation process, with attacks ranging from moderate to severe. This pest can reduce the quality and quantity of mustard plants, thus affecting plant productivity. This study aims to determine the level of concentration of Piairawi leaf extract (Haplolobus cf. monticola Husson) which is effective for controlling the tritip caterpillar ( $P$. xylostella $L$ ). This research was carried out in the Laboratory and Screen House of Plant Pests and Diseases, Faculty of Agriculture, University of Papua in February - April 2019. The study used a randomized block design with 5 treatments and 5 replications. Laboratory treatments consisted of concentrations of $20 \mathrm{ml} / \mathrm{l}, 40 \mathrm{ml} / \mathrm{l}, 60 \mathrm{ml} / \mathrm{l}, 80 \mathrm{ml} / \mathrm{l}$ and $100 \mathrm{ml} / \mathrm{l}$, while for the treatment at the Screen House using concentrations of O (control), $45 \mathrm{ml} / \mathrm{l}, 50 \mathrm{ml} / \mathrm{l}, 55 \mathrm{ml} / \mathrm{l}$ and $60 \mathrm{ml} / \mathrm{l}$. Observation variables included Larval Mortality, Efficacy Percentage and Damage Intensity. Piairawi leaf extract insecticide given had a significant effect on larval mortality, efficacy and intensity of damage. Giving extract in P1-P4 treatment $(45-60 \mathrm{ml} / \mathrm{l})$ was able to kill P. xylostella lava by $52 \%-68 \%$ and was able to suppress larval attack by $31.67 \%-44.84 \%$. The greater the concentration level given, the more mortality and intensity of damage from P. xylostella larvae to mustard plants
\end{abstract}

Keywords:

Piairawi leaf,

Plutella

xylostella $L$

Mustard,

toxicity,

Tritip

caterpillar

\section{Kata Kunci: ABSTRAK}

daun piairawi,

Sawi banyak digemari oleh masyarakat sebagai bahan pangan (sayuran) baik untuk konsumsi segar maupun diolah, memiliki kandungan vitamin dan zat gizi yang sangat penting bagi kesehatan. Salah satu penyebab terjadinya penurunan produksi sawi adalah akibat serangan hama ulat tritip

Plutella xylostella $\mathrm{L}$ (Plutella xylostella L.) yang mengganggu proses pembudidayaan tanaman sawi, dengan tingkat serangan mulai dari sedang hingga berat. Hama ini dapat menurunkan kualitas dan kuantitas tanaman sawi, sehingga berpengaruh terhadap produktivitas tanaman. Penelitian ini bertujuan

Sawi, untuk menentukan tingkat konsentrasi ekstrak daun Piairawi (Haplolobus cf. monticola Husson) yang efektif untuk mengendalikan hama ulat tritip ( $P$. xylostella L). Penelitian ini dilaksanakan di

Toksisitas, Laboratorium dan Screen House Hama dan Penyakit Tumbuhan Fakultas Pertanian Universitas Papua pada bulan Februari - April 2019. Penelitian menggunakan Rancangan Acak Kelompok dengan perlakuan 5 perlakuan dan 5 ulangan Perlakuan di Laboratorium terdiri dari konsentrasi

Ulat tritip $20 \mathrm{ml} / 1,40 \mathrm{ml} / 1,60 \mathrm{ml} / 1,80 \mathrm{ml} / 1$ dan $100 \mathrm{ml} / 1$, sedangkan untuk perlakuan di Screen House menggunakan konsentrasi 0 (kontrol), $45 \mathrm{ml} / 1,50 \mathrm{ml} / 1,55 \mathrm{ml} / 1$ dan $60 \mathrm{ml} / 1$. Variabel pengamatan meliputi Mortalitas Larva, Persentase Efikasi dan Intensitas Kerusakan. Insektisida ekstrak daun Piairawi yang diberikan mempunyai pengaruh yang nyata terhadap mortalitas larva, efikasi dan intensitas kerusakan. Pemberian ekstrak pada perlakuan P1-P4 (45-60 ml/l) mampu membunuh lava $P$. xylostella sebesar 52\%-68\% dan mampu menekan serangan larva sebesar $31.67 \%-44,84 \%$. Semakin besar tingkat konsentrasi yang diberikan maka akan meningkatkan mortalitas dan intensitas kerusakan dari larva P. xylostella terhadap tanaman sawi. 


\section{PENDAHULUAN}

Sawi banyak digemari oleh masyarakat sebagai bahan pangan (sayuran) baik untuk konsumsi segar maupun diolah. Sawi memiliki kandungan vitamin dan zat gizi yang sangat penting bagi Kesehatan (Yulia et al., 2011). Zulkarnain (2009) menyatakan bahwa kebutuhan sawi mengalami peningkatan seiring dengan meningkatnya jumlah penduduk, sawi mempunyai nilai ekonomi tinggi setelah tanaman kubis crop, kubis bunga dan brokoli. Dalam proses budidaya tanaman sawi, kendala yang utama yang dihadapi adalah gangguan organisme pengganggu tanaman (OPT).

Produktivitas sayuran sawi di Manokwari mengalami penurunan dari 2,93 ton/ha menjadi 2,08 ton/ha (Badan Pusat Statistik Papua Barat, 2017). Salah satu penyebab penurunan produksi yaitu sering adanya serangan hama ulat tritip (Plutella xylostella L.), upaya yang dilakukan petani cenderung menggunakan insektisida kimia sintetik secara intensif. Dampak penggunaan insektisida sintetik yang tidak bijaksana secara terus menerus dengan interval waktu yang pendek telah diketahui menyebabkan resistensi, resurjensi dan terbunuhnya musuh alami dan menimbulkan pencemaran lingkungan serta terganggunya kesehatan bagi petani dan konsumen (Budartini et al., 2018).

Upaya yang bisa dilakukan untuk menekan penggunaan insektisida sintetik adalah dengan menggunakan senyawa kimia yang berasal dari tumbuhan atau zat metabolit sekunder sebagai bahan aktif insektisida nabati (Hasyim, 2010). Pemanfataan insektisida nabati sebagai alternatif pengendalian serangga hama relative aman, murah, lebih bersifat spesifik, ramah lingkungan, residu lebih pendek dan mudah terurai dialam (Budartini et al., 2018). Mekanisme kerja insektisida nabati terhadap serangga hama yaitu menghambat proses reproduksi serangga betina, mengurangi nafsu makan, merusak perkembangan telur, larva dan pupa, serta menghambat pergantian kulit (Baharudin, 2015).

Tanaman buah hitam dari hasil penlitian Lekitoo et al. (2012) dilaporkan ada 15 jenis yang terdapat di Papua dan Papua Barat, salah satunya adalah jenis Haplolobus cf. monticola. Jenis ini tumbuh pada hutan dataran rendah bersama-sama dengan vegetasi berkayu lainnya membentuk hutan hujan tropis dataran rendah, penyebarannya di Papua dan Papua Barat antara lain di daerah Boven Digul (Tanah Merah) Merauke, Pulau Yapen, Pulau Numfor, Nabire, dan di Teluk Wondama. Jenis buah hitam yang terdapat pada semenanjung Wandamen berbeda dengan buah hitam yang terdapat di Boven Digul, Pulau Numfor dan Pulau Yapen. Masyarakat suku Wandamen di Kabupaten Teluk Wondama membudidayakan tumbuhan ini, meskipun sebagian besar Buah hitam masih terdapat secara alami pada hutan alam. Setiap keluarga asli suku Wandamen memiliki rata-rata 5-15 pohon buah hitam (Lekitoo et al., 2012; Ungirwalu et al., 2016). Tanaman buah hitam (Haplolobus cf. monticola Husson.) asal Wondama, oleh masyarakat setempat menyebutnya Piairawi. Hasil penelitian Somar (2012), daun piairawi memiliki kandungan metabolik sekunder tannin yang tinggi berkisar 8,34-37,26\% dibandingkan flavonoid dan alkanoid. Senyawa flavonoid dan alkanoid merupakan senyawa yang dapat menghambat proses pencernaan dan juga bersifat toksik bagi serangga, sedangkan senyawa tanin merupakan senyawa aktif metabolik sekunder yang dapat digunakan oleh tumbuhan sebagai pelindung dari serangan hama (Chintihia, 2015).

Penelitian ini bertujuan untuk menentukan tingkat konsentrasi ekstrak daun Piairawi yang efektif untuk mengendalikan dan membunuh hama $P$. xylostella. Hasil penelitian ini diharapkan dapat menambah pengetahuan petani dan 
masyarakat mengenai manfaat daun Piairawi dalam mengendalikan hama $P$. xylostella pada tanaman sawi

\section{BAHAN DAN METODE}

Penelitian ini dilaksanakan di Laboratorium Hama dan Penyakit Tumbuhan dan Screen House, Fakultas Pertanian Universitas Papua. Berlangsung pada bulan Februari sampai April 2019.

Bahan yang digunakan yaitu daun Piairawi asal Kabupaten Teluk Wondama, larva P. xylostella yang diperoleh dari hasil rearing di laboratorium, benih sawi, daun kubis untuk pakan larva, pupuk kotoran kambing, polibag berukuran $30 \times 30 \mathrm{~cm}$, plastik bening, madu untuk pakan imago, air mineral, kain tile, kertas label, masker, tisu, alumunium foil, kapas, kayu lat, paku 3, alkohol 96\%, detergen colek (B29) dan lakban. Alat yang digunakan dalam penelitian ini adalah jaring serangga, meter, kulkas, gelas ukur, erlenmeyer, timbangan digital, hotplate, blender, petridish, kain saring, corong, hand sprayer, nampan, pengaduk, ember, gunting, pinset, sarung tangan, botol, toples, kuas kecil, alat tulis, dan kamera.

Penelitian ini terdiri dari 2 rangkaian penelitian yaitu uji pendahuluan di Laboratorium dan penelitian lanjutan (utama) di Screen House.

\section{Uji Pendahuluan}

Dilakukan bertujuan untuk mencari konsentrasi insektisida nabati yang tepat, yang akan digunakan dalam penelitian. Penentuan konsentrasi yang akan digunakan, ditentukan dari kemampuan masing-masing konsentrasi yang mampu membunuh larva sebanyak $50 \%$ dalam waktu 24 jam. Konsentrasi yang diuji yaitu $20 \mathrm{ml} / 1,40 \mathrm{ml} / 1,60 \mathrm{ml} / 1,80 \mathrm{ml} / 1$ dan 100 $\mathrm{ml} / \mathrm{l}$ dengan 5 ulangan, sehingga terdapat 25 satuan percobaan. Uji ini dilakukan dengan menggunakan metode pencelupan pakan pada setiap konsentrasi. Larva uji F1 merupakan hasil perkembangbiakan (rearing) di laboratorium. Larva uji yang digunakan sebanyak 5 larva per petridish dilaparkan terlebih dahulu selama 1 jam. Pengamatan dilakukan selama periode 24 jam, yaitu pada jam ke-1, jam ke-2, jam ke4, jam ke-6, jam ke-12, dan jam ke-24.

Dari hasil uji pendahuluan yang dilakukan, mortalitas larva yang lebih dari $50 \%$ terdapat pada konsentrasi $60 \mathrm{ml} / 1$ yaitu sebesar 64\%, sedangkan untuk konsentrasi $40 \mathrm{ml} / 1$ mempunyai mortalitas larva sebesar 48\%. Selanjutnya kisaran konsentrasi 40-60 ml/1 digunakan sebagai uji toksisitas lanjutan (utama), yaitu 45 $\mathrm{ml} / 1,50 \mathrm{ml} / \mathrm{l}, 55 \mathrm{ml} / \mathrm{l}$ dan $60 \mathrm{ml} / \mathrm{l}$.

\section{Penelitian Lanjutan (utama),}

Menggunakan metode eksperimen Rancangan Acak Lengkap (RAL) yang terdiri atas 5 perlakuan: P0: Kontrol, P1: $45 \mathrm{ml} / 1, \mathrm{P} 2: 50 \mathrm{ml} / 1, \mathrm{P} 3: 55 \mathrm{ml} / 1, \mathrm{P} 4: 60 \mathrm{ml} / 1$ dan 5 ulangan sehingga terdapat 25 satuan percobaan.

Tahapan pelaksanaan penelitian adalah sebagai berikut:

\section{Persiapan Kotak Pembiakan Serangga Uji}

Kotak ukuran $15 \times 15$ × $15 \mathrm{~cm}$, bagian sisi kiri, kanan, atas dan belakang kotak ditutup dengan kain tile yang bertujuan agar terjadi pertukaran udara serangga imago Plutella xylostela.

\section{Pembiakan serangga uji}

Dilakukan dengan mengumpulkan imago $P$. xylostella dari lapangan dan dipelihara di laboratorium dengan menggunakan kotak pemeliharaan sampai generasi ke-3 kemudian dikawinkan dengan imago dari lapangan dengan tujuan mendapatkan (F1) murni dari laboratorium.sampai imago F1 menghasilkan jumlah populasi instar III yang cukup seragam untuk pengujian. 


\section{Persiapan Bibit dan Penanaman}

Benih sawi disemai pada nampan, bibit berumur 10 hari dipindahkan ke polybag berisi media tanam tanah dan pupuk kotoran kambing, berisi 1 tanaman sawi.

\section{Pemeliharaan Serangga Uji dan Tanaman}

Pemeliharaan serangga uji di laboratorium dilakukan setiap hari dengan penggantian pakan, sedangkan pemeliharaan tanaman meliputi penyiraman, penyiangan dan penyulaman.

\section{Pembuatan Ekstrak Daun Piairawi}

Daun Piairawi diambil dari Kampung Maniwak, Kabupaten Teluk Wondama yang digunakan sebagai bahanekstrak insektisida nabati adalah daun ketiga dan keempat dari pangkal ranting pohon, dikeringkan, kemudian di gunting kecil-kecil, selanjutnya diblender halus. Ditimbang 150 gram dimasukan kedalam labu erlenmeyer $1000 \mathrm{ml}$ dan dimaserasi selama $3 \times 24$ jam dalam $1000 \mathrm{ml}$ alkohol 96\% sambil kadang-kadang diaduk (Somar, 2012). Setelah dimaserasi, dilakukan pemanasan untuk menguapkan alkohol dengan menggunakan hotplate +/20 menit sambil diaduk, ekstrak disaring menggunakan kain saring dalam labu erlenmeyer $500 \mathrm{ml}$, ditutupi dengan aluminium foil, disimpan dalam kulkas. Untuk aplikasi pada uji lapangan, ektrak cair daun Piairawi dilakukan pengenceran dengan air mineral dan sabun sesuai konsentrasi perlakuan yang digunakan.

\section{Pemberian Perlakuan}

Aplikasi ekstrak $50 \quad \mathrm{ml} /$ polybag dilakukan penyemprotan menggunakan hand sprayer pada tanaman sawi berumur 28 hari sesuai perlakuan konsentrasi yang diuji. Larva uji dilaparkan dulu selama 1 jam, diinfeksikan pada tanaman, masingmasing sebanyak 10 larva instar III.

\section{Variabel Pengamatan}

Variabel Pengamatan meliputi: 1). Mortalitas Larva: dilakukan pada 24 jam setelah aplikas, perhitungan menggunakan rumus persentase mortalitas dari Sinaga (2009) dalam Setiawan \& Supriyadi, (2014):

Keterangan :

$$
\mathrm{M}=\frac{a}{a+b} \times 100 \%
$$

$\mathrm{M}=$ Persentase mortalitas

$\mathrm{a}=$ Jumlah yang mati

$\mathrm{b}=$ Jumlah yang hidup

2). Persentase Efikasi: perhitungan menggunakan rumus Abbott (1925) dalam Martono (1999) :

Keterangan:

$$
E=((C-T) / C) \times 100 \%
$$

Bila sebelum aplikasi, populasi hama di semua plot sama.

$\mathrm{E}=$ Efikasi pestisida (\%)

$\mathrm{C}=$ Jumlah larva yang masih hidup pada control.

$\mathrm{T}=$ Jumlah larva hidup pada perlakuan.

3). Intensitas Kerusakan: Luhukay et al., 2018) mengemukakan bahwa untuk menghitung intensitas serangan larva Plutella xylostella L. digunakan rumus sebagai berikut:

$$
P=\left(\sum \llbracket(n \times V) \rrbracket\right) / Z N \times 100 \%
$$

Keterangan:

$\mathrm{P} \quad=$ Intensitas serangan (\%).

$\mathrm{n} \quad=$ Jumlah daun yang diamati tiap kategori serangan.

$\mathrm{v}=$ nilai skala dari setiap kategori serangan.

$\mathrm{Z}=$ nilai skala tertinggi yang digunakan.

$\mathrm{N} \quad=$ Jumlah daun yang diamati. 
Tabel 1. Kriteria Kategori Intensitas Serangan

\begin{tabular}{ccc}
\hline Kategori & Persentase & Kriteria \\
\hline 0 & 0 & Normal \\
1 & $0<25$ & Ringan \\
2 & $25<50$ & Sedang \\
3 & $50<75$ & Berat \\
4 & $>75$ & Sangat berat \\
\hline
\end{tabular}

\section{Analisis Data}

Analisis Data dianalisis dengan menggunakan Anova pada taraf 95\% dan uji lanjut BNJ.

\section{HASIL DAN PEMBAHASAN}

Mortalitas larva Plutella xylostella dan Efikasi Ekstrak Daun Piairawi

Hasil penelitian pengaruh konsentrasi ekstrak daun Piairawi terhadap pengamatan persentase mortalitas larva $P$. xylostella L. dan persentase efikasinya, disajikan pada Tabel 2, Diagram 1 dan 2.

Tabel 2. Rata-rata Persentase Mortalitas P. xylostella L.dan Persentase Efikasi Ekstrak Daun Piairawi dengan Perlakuan Berbagai Konsentrasi Ekstrak Daun Piairawi

\begin{tabular}{lll}
\hline Perlakuan & Mortalitas (\%) & Efikasi (\%) \\
\hline P0 (0) & $6,00^{\mathrm{c}}$ & $0^{\mathrm{c}}$ \\
P1 (45 ml/l) & $52,00^{\mathrm{b}}$ & $48,61^{\mathrm{b}}$ \\
P2 (50 ml/l) & $54,00^{\mathrm{b}}$ & $50,89^{\mathrm{b}}$ \\
P3 (55 ml/l) & $62,00^{\mathrm{ab}}$ & $59,39^{\mathrm{ab}}$ \\
P4 (60 ml/l) & $68,00^{\mathrm{a}}$ & $65,61^{\mathrm{a}}$ \\
\hline Nilai BNJ & 13,90 & 13,50 \\
\hline
\end{tabular}

Keterangan : Angka-angka yang dikuti dengan huruf yang sama pada kolom yang sama menunjukkan tidak berbeda nyata berdasarkan uji BNJ pada taraf kesalahan 5\%.

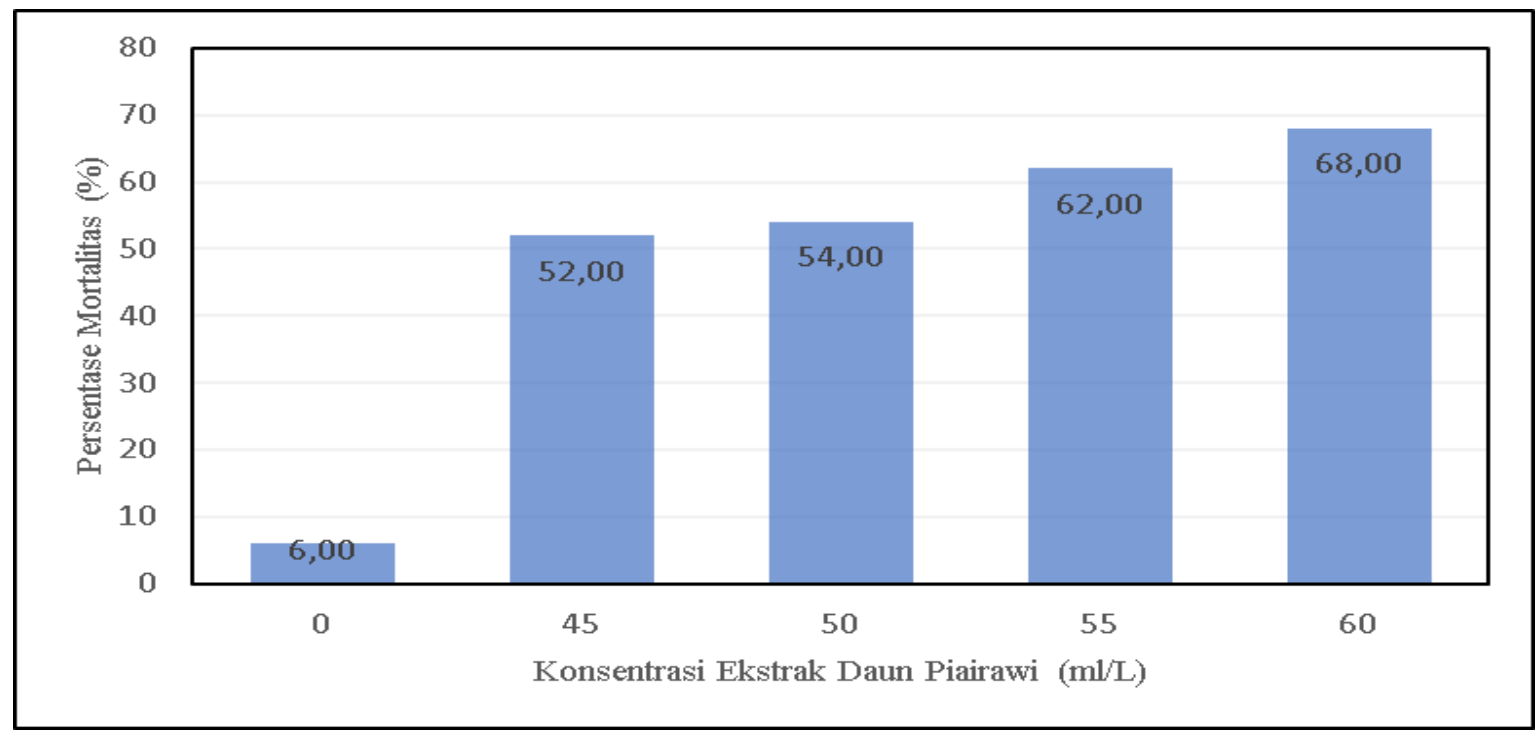

Gambar 1. Rata-rata Persentase Mortalitas Larva P. xylostella dengan Perlakuan berbagai Konsentrasi Ekstrak Daun Piairawi 


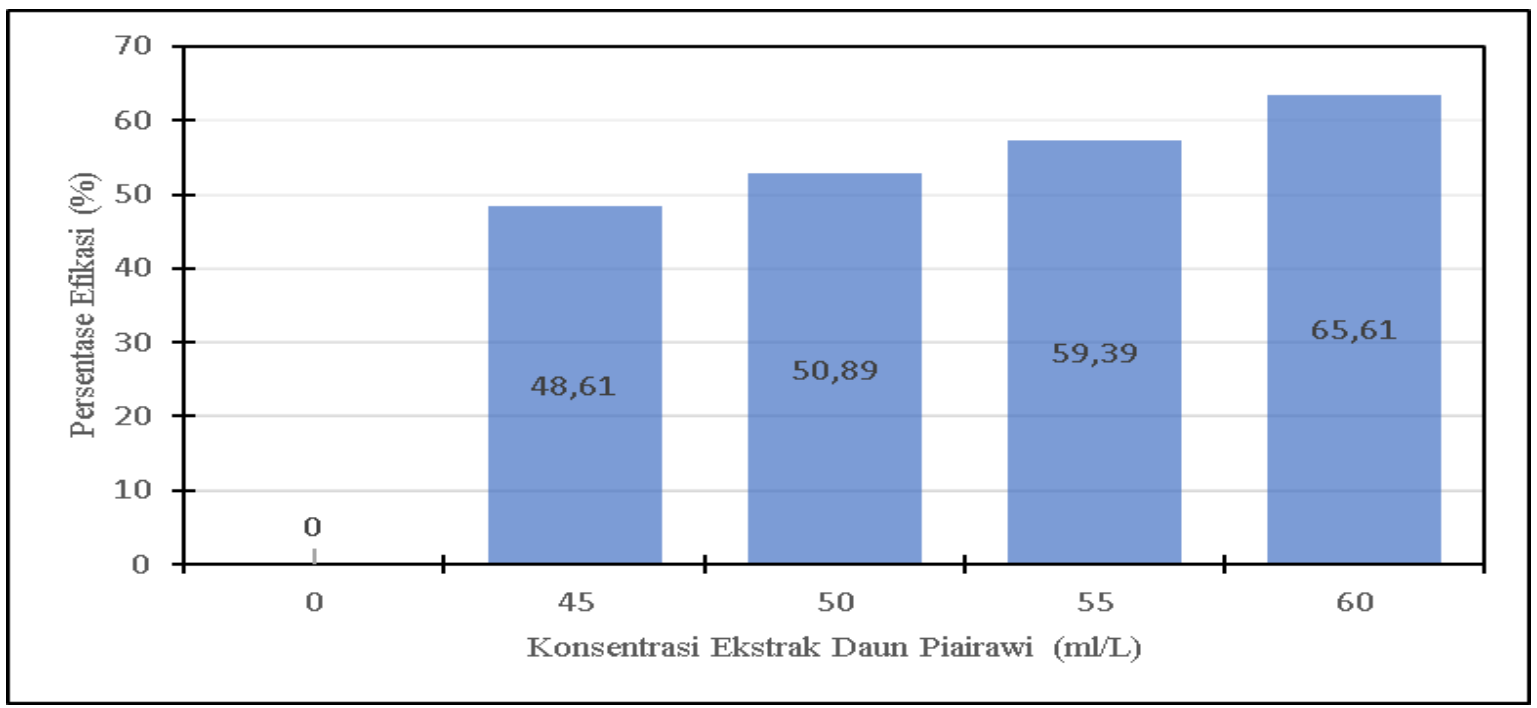

Gambar 2. Rata-rata Persentase Efikasi Ekstrak Daun Piairawi dengan Perlakuan berbagai Konsentrasi Ekstrak Daun Piairawi

Pada Tabel 2 terlihat bahwa perlakuan aplikasi insektisida mempunyai pengaruh yang nyata terhadap persentase mortalitas larva. Tingginya konsentrasi insektisida akan meningkatkan persentase mortalitas larva (Diagram 1), konsentrasi $60 \mathrm{ml} / \mathrm{l}$ memberikan pengaruh paling baik dibandingkan konsentrasi lainnya, tetapi tidak berbeda dengan konsentrasi $55 \mathrm{ml} / \mathrm{l}$, sedangkan konsentrasi $55 \mathrm{ml} / 1$ sama dengan konsentrasi 45 dan $50 \mathrm{ml} / 1$.

Berdasarkan uji efikasi ekstrak daun Piairawi menunjukkan bahwa perlakuan P4 mempunyai persentase efikasi terbesar yaitu 65,61 dibandingkan perlakuan lainnya, tetapi tidak berbeda dengan perlakuan P3 (59,39\%). Selanjutnya perlakuan P3 sama dengan perlakuan P2 (50,89\%) dan P1 (48,61\%).

Tingginya kematian larva P.xylostella.akibat perlakuan insektisida nabati ekstrak daun Piairawi diduga adanya senyawa metabolit sekunder yaitu senyawa flavonoid, alkanoid dan tannin mempengaruhi pola makan larva P.xylostella. Hasil analisis laboratorium daun Piairawi oleh Somar (2012) kandungan senyawa tanin lebih tinggi yaitu 8,34\%-37,26\% dibandingkan flavonoid dan alkaloid. Hal ini sejalan dengan pendapat Solomon et al., (2014), bahwa senyawa tanin merupakan senyawa metabolik sekunder yang mempunyai kemampuan dalam mengendapkan protein pada sistem pencernaan serangga, sehingga dapat mengganggu proses pencernaan serangga juga sebagai pelindung dari serangan hama. Pendugaan selanjutnya bahwa. walaupun kandungan senyawa alkanoid dan flavonoid rendah kecenderungan dapat mempengaruhi mortalitas hama $P$. xylostella. Hal ini didukung hasil penelitian Astriani (2010) alkaloid mampu menghambat pertumbuhan larva dan menurunkan daya tahan tubuh, sedangkan penelitian Lina et al (2016) membuktikan bahwa flavonoid mampu menyebabkan denaturasi protein yang berujung pada tidak tersalurnya bahan makanan dan kekurangan ATP pada larva P. xylostella.

Berdasarkan tabel 2 dan Diagram 2, rata-rata persentase nilai efikasi ekstrak daun Piairawi mengalami kenaikan berdasarkan tingkat konsentrasi yang diberikan, kecuali kontrol. Bertambahnya dosis ekstrak daun ini berpengaruh signifikan terhadap nilai efikasi dan tingkat mortalitas larva. Hasil penelitian menunjukkan bahwa senyawa aktif flavonoid, alkaloid dan tannin pada ekstrak daun Piairawi mampu meracuni dan 
menghambat metabolisme larva P.xylostella L, Hal ini sejalan dengan pendapat Marhaeni et al. (2015) bahwa bahwa semakin tinggi konsentrasi yang digunakan,diikuti dengan bertambahnya waktu maka kandungan bahan aktif dalam larutan lebih banyak sehingga daya racun insektisida nabati semakin tinggi, bertambah pula lematian larva hama.

Perlakuan P1-P4 (45-60 $\mathrm{ml} / \mathrm{l})$ mempunyai kemampuan yang efektif dalam mengendalikan larva P. xylostella $\mathrm{L}$. yang menyerang tanaman sawi. Keefektifan suatu insektisida dapat dinilai berdasarkan banyaknya populasi hama yang hidup ataupun yang mati setelah

pemberian perlakuan, ataupun berdasarkan kemampuan konsentrasi insektisida nabati untuk mematikan hama uji lebih dari 50\% dalam kurun waktu 24 jam setelah aplikasi (Kardinan, 2011).

\section{Intensitas Kerusakan Larva $\boldsymbol{P}$. xylostella setelah Aplikasi Ekstrak}

Hasil pengamatan terhadap intensitas kerusakan akibat serangan larva $P$. xylostella dari 5 perlakuan (Tabel 3 dan Diagram 3) menunjukkan bahwa pemberian insektisida nabati berpengaruh nyata terhadap persentase intensitas serangan.

Tabel 3. Rata-rata Persentase Intensitas Kerusakan Larva P. xylostella pada Tanaman Sawi.

\begin{tabular}{lll}
\hline Perlakuan & Intensitas Kerusakan $(\%)$ & Kategori \\
\hline P0 $(0)$ & $53,22^{\mathrm{b}}$ & Berat \\
P1 $(45 \mathrm{ml} / 1)$ & $44,84^{\mathrm{ab}}$ & Sedang \\
P2 $(50 \mathrm{ml} / 1)$ & $42,15^{\mathrm{ab}}$ & Sedang \\
P3 $(55 \mathrm{ml} / 1)$ & $35,09^{\mathrm{a}}$ & Sedang \\
P4 $(60 \mathrm{ml} / \mathrm{l})$ & $31,67^{\mathrm{a}}$ & Sedang \\
\hline Nilai BNJ & 13,40 & \\
\hline
\end{tabular}

Keterangan : Angka-angka yang dikuti dengan huruf yang sama pada kolom yang sama menunjukkan tidak berbeda nyata berdasarkan uji BNJ pada taraf kesalahan 5\%.

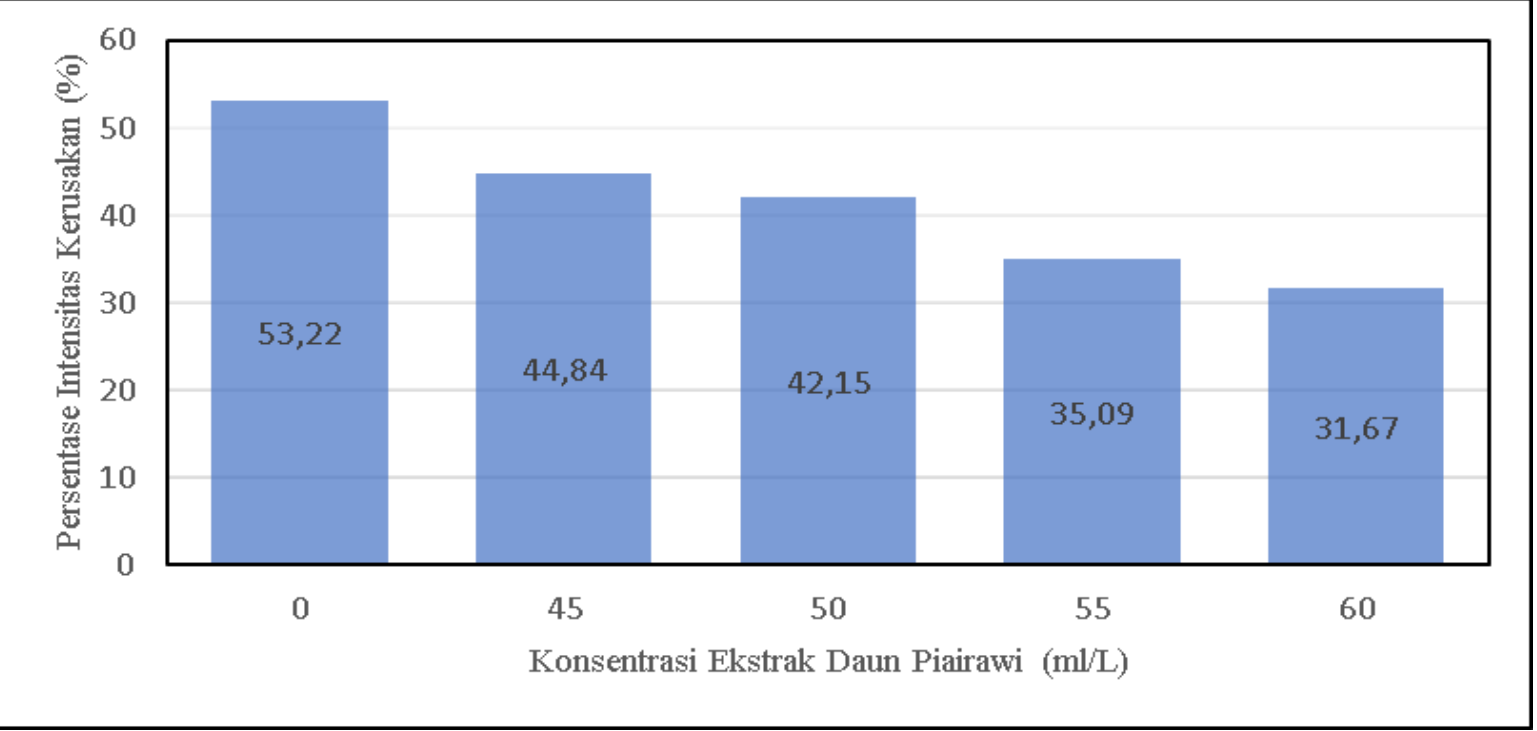

Diagram 3. Rata-rata Persentase Intensitas Kerusakan Daun Sawi akibat Pemberian berbagai Konsentrasi Ekstrak Daun Piairawi 
Perlakuan konsentrasi $60 \quad \mathrm{ml} / \mathrm{l}$ memberikan pengaruh paling baik dengan nilai serangan terendah $(31,67 \%)$ dibandingkan konsentrasi lainnya, tetapi tidak berbeda dengan konsentrasi $55 \mathrm{ml} / 1$ $(35,09 \%)$. Selanjutnya konsentrasi $55 \mathrm{ml} / 1$ sama dengan konsentrasi $50 \mathrm{ml} / 1(42,15 \%)$, $45 \mathrm{ml} / \mathrm{l}(44,84)$ dan kontrol $(53,22 \%)$.

Intensitas kerusakan akibat serangan larva $P$. xylostella menunjukkan bahwa perlakuan insektisida nabati memberikan pengaruh terhadap tingkat serangan. Pada perlakuan kontrol (P0) mempunyai tingkat serangan tertinggi, dengan kategori serangan berat. Sedangkan pada perlakuan P1-P4 (45-60 $\mathrm{ml} / \mathrm{l})$ mempunyai nilai persentase yang semakin rendah, dengan kategori serangan sedang. Semakin tinggi konsentrasi insektisida yang diberikan maka akan menekan laju peningkatan serangan larva $P$. xylostella terhadap tanaman sawi. Hal ini sejalan dengan hasil penelitian Putra (2014), bahwa semakin tinggi konsentrasi yang digunakan, maka kandungan bahan aktif dalam larutan lebih banyak sehingga daya racun dari insektisida nabati semakin tinggi yang dapat menghambat aktivitas hama. Proses metabolisme dan aktivitas makan dari larva $P$. xylostella dapat terganggu karena adanya interaksi antara senyawa aktif yang terkandung pada daun Piairawi, yang menyebabkan intensitas serangan semakin menurun. Menurut (Lina et al., 2016), antara senyawa flavonoid dan senyawa tanin mengganggu proses metabolisme dari larva $P$. xylostella, selanjutnya senyawa flavonoid dapat mengakibatkan denaturasi protein yang berujung pada tidak tersalurnya bahan makanan dan kekurangan ATP sedangkan tanin menurunkan aktivitas enzim protease dan kekurangan energi ATP sehingga mengakibatkan sintesis protein tidak dapat berlangsung dan ATP tidak akan terbentuk. Dugaan lebih lanjut bahwa kombinasi dua senyawa yang terdapat pada ekstrak daun Piairawi dapat meningkatkan nilai efikasi, dan tidak disukainya tanaman oleh serangga hama waktu beraktifitas dan merusak tanaman. Hal ini didukung oleh hasil penelitian Wahid (2010) menyatakan bahwa kombinasi dapat meningkatkan efektivitas, sehingga terjadi sinerginitas pengendalian.

\section{KESIMPULAN}

Berdasarkan hasil penelitian dapat disimpulkan bahwa perlakuan P1 (45 ml/l) merupakan konsentrasi ekstrak daun Piairawi (Haplolobus cf. monticola Husson.) yang efektif untuk mengendalikan hama Tritip (Plutella xylostela L.)

Persentase efikasi yang efektif dalam mengendalikan hama P. xylostella berada pada perlakuan $\mathrm{P} 2(50 \mathrm{ml} / \mathrm{l})$ dengan nilai persentase efikasi, yaitu 50,89\%.

Persentase intensitas kerusakan tertinggi terdapat pada perlakuan $\mathrm{P} 0$ (kontrol) dengan nilai persentase 53,22\%, sedangkan persentase intensitas terendah pada perlakuan P4 $(60 \quad \mathrm{ml} / \mathrm{l})$ nilai persentasenya adalah $31,67 \%$, semakin besar tingkat konsentrasi insektisida maka intensitas serangan akan semakin kecil.

\section{DAFTAR PUSTAKA}

Astriani, D. (2010). Pemanfaatan Gulma Babadotan Dan Tembelekan Dalam Pengendalian Sitophilus Spp Pada Benih Jagung. Jurnal AgriSains, 1(1).

Badan Pusat Statistik Papua Barat. (2017). Provinsi Papua Barat Dalam Angka.

Baharudin, B. (2015). Penggunaan pestisida nabati untuk mengendalikan hama dan penyakit pada tanaman pangan, industri dan hortikultura. In Prosiding Seminar Nasional Agribisnis (pp. 37-50).

Budartini, N. i K., Yuliadhi, K. A., \& Sritamin, M. (2018). Uji Efektivitas Beberapa Ekstrak Daun Tanaman terhadap Populasi Ulat Daun Kubis (Plutella xylostella L.) pada Tanaman Kubis di Lapang. Jurnal Agroteknologi Tropika., 7(3), 316-325. 
Chintihia, T. (2015). Efek Larvasida Ekstrak Daun Cengkeh (Syzygium aromaticum L.) terhadap Aedes aegypti. Jurnal Agromedicine, 2(4), 510-515.

Hasyim, A. (2010). Efikasi dan Persistensi Minyak Sereh Wangi sebagai Biopestisida terhadap Helicoverpa aemigera. Balai Penelitian Tanaman Sayuran, Lembang.

Kardinan, A. (2011). Pestisida Nabati Ramuan dan Aplikasi. Penebar Swadaya.

Lekitoo, K., Batorinding, E., Dimomonmau, P. A., Rumbiak, W. F., C, H. D., \& H, Y. L. (2012). Pemanfaatan Enam Jenis Tumbuhan Hutan Penghasil Buah sebagai Sumber Bahan Pangan Ditanah Papua. . Badan Penelitian dan Pengembangan Kehutanan.

Lina, M., Suryadarma, I. G. P., \& others. (2016). Pengaruh Pemberian Ekstrak Daun Legundi (Vitex trifolia) sebagai Pestisida Nabati Pengendalian Hama Plutella xylostella pada Tanaman Sawi (Brassica juncea). Biologi-S1, 5(4), 34 40.

Luhukay, J. N., Uluputty, M. R., \& Rumthe, R. Y. (2018). Respons Lima Varietas Kubis (Brassica oleracea L.) Terhadap Serangan Hama Pemakan Daun Plutella Xylostella ( Lepidoptera; Plutellidae). Agrologia, https://doi.org/10.30598/a.v2i2.271

Marhaeni.J, Srie, K., Budiyono, W. ., \& Ervina, H. (2015). Pengaruh Beberapa Konsentrasi Ekstrak Biji Sirsak (Annona muricata L.) terhadap Perkembangan Spodoptera litura (Lepidoptera, Noctuidae).

Martono, E. (1999). Pertimbangan Fluktuasi Populasi dalam Perhitungan Efikasi Pestisida. Jurnal Perlindungan Tanaman Indonesia , 5(1), 60-66.

Putra, F. (2014). Konsentrasi Fraksi Heksan Bunga Kipait (Tithonia diversifolia A. Gray) (Asteraceae) Terhadap Larva Plutella xylostella Linn (Lepidoptera:Yponomeutidae).

Universitas Andalas.
Setiawan, A. N., \& Supriyadi, A. (2014). Uji Efektivitas Berbagai Konsentrasi Pestisida Nabati Bintaro (Cerbera manghas) terhadap Hama Ulat Grayak (Spodoptera litura) pada Tanaman Kedelai. Planta Tropika: Jurnal Agrosains (Journal of Agro Science), 2(2), 99-105.

Solomon-Wisdom, Ugoh, S. C., \& Mohammed. (2014). Phytochemical Screening and Antimicrobial activities of Annona muricata (L) leaf extract. American Journal of Biological, Chemical and Pharmaceutical SciencesOnline) American Journal of Biological, Chemical and Pharmaceutical Sciences, 2(1).

Somar, E. (2012). Lima Pengaruh Faktor Abiotik Terhadap Kandungan Metabolit Sekunder Daun Piairawi (Haplolobus cf. monticola Husson.). Universitas Papua.

Ungirwalu, A., Maryudi, A., Suryanto, P., \& others. (2016). Pengelolaan Adaptif Pemanfaatan Buah Hitam (Haplolobus monticola blumea) etnis wandamenpapua. Jurnal Manusia Dan Lingkungan, 23(2), 266-275.

Wahid, A. (2010). Efikasi Bioinsektisida Dan Kombinasinya Terhadap Serangan Hama Ulat Kantong Pagodiella spp. Pada Bibit Mangrove Rhizophora spp. di Persemaian. Agroland: Jurnal IlmuIlmu Pertanian, 17(2).

Yulia, A. E., Murniati, \& Fatimah. (2011). Aplikasi Pupuk Organik pada Tanaman Sawi untuk Dua Kali Penanaman. Jurnal Sagu, 10(1), 14-19.

Zulkarnain, Z. (2009). Dasar-dasar hortikultura. PT Bumi Aksara. 